\title{
KrITIK Atas IMAN
}

\section{Muhammad Anwar Firdausy}

Dosen Fakultas Humaniora dan Budaya Universitas Islam Negeri (UIN) Malang

\section{Abstract}

In the preceding discussion the term "faith" has been used in a variety of senses. We have used the term to refer to the a sumption, conviction and attitudes which the believer brings to the evidence for and against religious truth. We have also used the term to refer the commitment which is some respects the outcome of this reflection. We have used faith to refer to the subjective preferences of people generallly. Faith is all of these, though this must not be taken as impliying there are no significant differences between the various kinds of faith. In a sense, every person has "faith"; everyone has deep-rooted assumption, convictionsand attitudes which color what counts as evidence for him and how that evidence is interpreted. This.is the kind of faith which one brings to the evidence. Insofar as beliefs are reflected in action, and people must make choices, everyone also has faith in the sense of commitments which may or may not be informed by rational reflection.

Keywords: faith, reflection.

\section{A. Pendahuluan}

Term Iman sudah sering dikupas dan diuraikan dalam berbagai forum diskusi, sebab iman itu sendiri memang tak pernah luput dari dinamika kehidupan manusia dan tentu saja harus selalu diperbincangkan tanpa merasa jenuh atau bosan, mengingat anomali yang terkandung didalamnya tak akan pernah habis diperdebatkan.

Dalam kehidupan manusia, permasalahan iman bukanlah sesuatu yang bersifat pelengkap sehingga bisa dikesampingkan atau ditinggalkan begitu saja. Sungguh tidak mungkin sebab dia merupakan perkara yang terkait dengan penentuan nasibnya. Bahkan secara fungsional ia merupakan penentu nasib hidup manusia yang paling urgen (Yusuf Qardhawi:1999,5).

Iman itu tidaklah cukup bila hanya beriman saja kemudian meniggalkannya, dan juga tidak cukup hanya dengan "beriman kepada Allah". Iman tentunya harus berlaku juga pada obyek-obyek keimanan, dan hanya orang 
yang beriman pada seluruh obyek keimanan, keimanannya dapat dipandang sebagai keimanan islam (Sachico Murata \& William C. Chittick: 1997, 13).

Iman sepertinya melahirkan muatan beragam yang tuntutannya bisabisa sangat berat untuk mengcovernya sebagai ujian dari Allah. Apabila iman berarti sikap percaya sepenuhnya kepada Allah dan mempercayaiNya, maka iman harus tetap dijaga kemurniannya, sehingga dapat membawa bahtera kita terhadap kebahagiaan sejati lahir dan batin. Sebab.iman akan menimbulkan nuansa aman hanya jika tidak tercampur oleh hal-hal yang dapat mengotori iman itu yaitu perbuatan dosa.Sebagaimana menjadi diskursus bagi para mutakallimin, sebab terdapat potensi ataupun peluang kemungkinan seseorang yang beriman mengotori imannya dengan kejahatan atau perbutan dosa, yang tentu tidak diperkenankan olehNya, dan peristiwa:tersebut sering terjadi. Karena manusia mempunyai kebebebasan untuk menentukan sendiri perbuatannya secara ihtiariah. Artinya perbuatan yang dinisbatkan kepada manusia dan menjadi tanggungjawabnya. Sebab ia mempunyai kemampuan untuk melakukan atau meninggalkannya (NurCholihs Madjid: 1994, 6). Melihat peristiwa tersebut akhirnya dimana makna hakekat iman itu sendiri ?

Tampaknya iman memang kerapkali membawa nuansa aman, sehingga membuat orang mempunyai amanat itu tentu lebih baik daripada hanya percaya, dalam arti sekedar percaya akan adanya Tuhan-dapat dicatat bahwa syetanpun yang terkutuk percaya kepada Tuhan, bahkan Iblis sempat berdialog dan berargumentasi dengan Tuhan- (Nurcholish Madjid: 1992, 94). Dalam perkataan mempercayai Tuhan atau menaruh kepercayaan terhadapNya terkandung pengertian sikap kepasrahan menyandarkan diri kepadaNya yang mutlak, sehingga percaya akan eksistensiNya.

Namun perlu diperhatikan dengan mempersoalkan nilai pengakuan atau kepercayaan kepada Allah dalam agama belum dibahas apakah mungkin Allah.dapat dibuktikan adanya secara rasional, jika memang demikian, verifikasi itu hanya berguna bagi tidak banyak orang, yakni orang-orang terdidik yang telah belajar secara ilmiah. Mayoritas orang tidak sampai pada suatu pengertian macam ini. Bagi mereka pengakuan akan Allah terletak dalam percaya atau dengan pengalaman transcendental (metafisika) dapat ditemukan alasan untuk menggunakannya sebagai batu loncatan bagi peng- 
akuan Allah. Bisa dengan kata lain apakah kepercayaan akan Allah dapat. diterima oleh karena mengandung kebenaran, atau hanya memang menguntungkan (lebih enak percaya kepada Allah dari pada tidak) seperti yang diutarakan oleh salah satu pemikir modern W. James dan S, Freud (Theo Huijbes: 1992,58). Untuk itu perlulah jika kita menggali sekali lagi isi pengalaman hidup manusia guna menentukan bobot kebenaran yang terletak.dalam percaya.

\section{B. Iman Berhakekat Dinamis}

Tidak ada salahnya bila sedikit saya singgung kembali konsep iman, walupun pada pembahasan yang lau telah dikupas dari berbagai pendapat dengan beragam difinisinya. Iman amatlah erat sekali huburigannya dengan akal dan wahyu. Iman yang didasarkan pada wahyu disebut tasdiq, yaitu menerima sebagai benar apa yang didengar. Dan iman yang didasarkan pada akal disebut ma'rifah, mengerti benar dengan apa yang diyakini. Jadi tasdiq berdasarkan pada pemberitaan, sedangkan ma'rifah berdasarkan pada pengetahuan mendalam. (Harun Nasution: 1994,89)

Bagi Muhammad Abduh iman adalah pengetahuan, kepercayaan atau keyakinan. Dalam Tafsir al Manar ia menjelaskan bahwa iman adalah pengetahuan sebenarnya yang diperoleh akal melalui argumen-argumen kuat dan membawa jalan seseorang untuk tunduk dan menyerạh (Muhammad Abduh: $1336 \mathrm{H}, 111)$. Bahkan iman tidaklah sempurna kalau tidak didasarkan atas akal. Iman harus berdasar pada keyakinan, bukan pada pendapat, dan akallah yang menjadi sumber keyakinan itu padaTuhan, ilmu serta kemahakuasaanNya serta para Rasul.

Lain halnya dengan Sachico Murata dan William C. Chittick, mereka mengutarakan konsep iman melalui apa yang disabdakan Nabi Muhammad SAW bahwa iman adalah sebuah pengakuan dengan hati, pengucapan dengan lisan dan aktivitas anggota badan. Jadi iman (faith) melibatkan pengakuan, pengucapan dan perbuatan. Sachico Murata \& William C. Chittick: 1997, 2) Oleh karenanya setiap orang yang beriman, pertama kali harus mengakui dalam hatinya bahwasanya sesuatu adalah benar. Sedangkan qolb.term yangdalam $\mathrm{Al}$ Qur'an sering dikaitkan dengan konteks 
iman utamanya bukan tempat bagi emosi melainkan ia merupakan fakultas (potensi pikir) yang spesifik, atau merupakan organ spiritual yang membedakan keberadaan manusia dibandingkan dengan non manusia. Atau juga pada umumnya kita ungkapkan dengan istilah intelegensi, dalam bahasa filosofis ia dapat disandingkan dengan rasional (berakal) sebagaimana dikatakan bahwasanya manusia adalah binatang berakal (rational animal) Sachico Murata \& William C. Chittick: 1997, 3). Artinya bila seseorang hatinya tidak berfungsi adalah seperti binatang, sebab sebuah hati hati yang sehat adalah hati yang mampu memahami sifat (nature) sesuatu, namun dalam Al Quran juga banyak yang menyatakan tentang hati yang menderita sakit atau terkunci, di antaranya yaitu ; .... Karena itu bukanlah mereka yang buta, melainkan yang buta adalah hati yang di dalam dada ...(22:46).

Menurut pandangan Nurcholish Madjid bila pengertian iman sebagai percaya tanpa konsekuensi yang nyata bisa tak bermakna dan absurd, mungkin mempercayai atau menaruh kepercayaan kepada Tuhan akan sedikit memperjelas makna iman itu (Nurcholish Madjid: 1992, 94).

Keimanan yang sebenarnya itu tidak cukup hanya sekedar pembenaran pikiran atau kepercayaan dalam hati, melainkan juga harus diwujudkan dalam perbuatan riil. Sejauh apapun perbedaan pendapat para ilmu kalam mengenai hubungan antara iman dan amal perbuatan; adalah amal perbuatan merupakan bagian dari iman, ataukah dia merupakan syarat dari iman, ataukah buah dari iman. Akan tetapi mereka tetaplah bersepakat bahwa amal perbuatan merupakan faktor yang tak bisa dipisahkan dari keimanan Mengenai hakekat iman Rasulullah SAW menyatakan: "Iman itu bukanlah merupakan harapan dan bukan pula perhiasan lahir, melainkan yang tertanam dalam hati dan dibuktikan oleh perbuatan " (HR. Ibnu Najjar dan Daelani). (Yusuf Qardhawi: 1999, 326-327).

Nurcholish Madjid juga menambahkan bahwa iman itu sendiri hakekatnya adalah suatu wujud atau kategori yang dinamis, artinya dapat berkembang atau menyusut, bertambah atau berkurang, naik turun, menguat atau melemah. Oleh sebab itu iman bukanlah wujud yang statis, artinya sesuatu yang sekali terbentuk, maka ia akan ada menurut bentuknya itu tanpa berubah, seperti layaknya sebuah bangunan fisik semisal monumen. Maka ada orangyang beriman namun masih sempat mengotori 
imannya dengan perbuatan dosa atau kejahatan adalah orang yang imannya masih lemah ((NurCholihs Madjid: 1994, 6).

Oleh karena itu iman pada hakekatnya dinamis, mengingat ia menyangkut hati atau bathin (qolb) bila di Indonesiakan menjadi kalbu yang secara terminologinya ialah sesuatu yang berganti-ganti. Maka tidak mungkin mendisain iman sedemikian rupa bentuknya hingga sekali jadi dan untuk selama-lamanya. Tapi setidaknya kita hendaknya berusaha menumbuhkan iman itu dalam diri kita sedemikian rupa, barangkali dari tingkat yang sederhana kemudian berkembang dan terus berkembang menuju kesempurnaan. Itu tandanya bahwasanya iman menuntut perjuangan terus-menerus, tanpa berhenti hingga mencapai pada tingkat iman hakiki.

\section{Manusia Percaya dan Tidak Dapat Percaya}

Adalah inti kehidupan beragam yaitu pengakuan bahwa Allah sungguh-sungguh ada, pengakuan ini disebut percaya (beriman). Sehingga percaya itu apakah merupakan sesuatu yang wajar, sesuatu yang masuk akal bagi orang-orang yang hidup pada abad XXI ini yang kecenderungannya kurang percaya akan sesuatu yang kurang nyata secara rasional.

Dari sini secara kritis bila renungkan bahwa seringkali orang-orang beragama tidak memperlihatkan sesuatu yang istimewa, seperti yang diharapkan dari orang-orang yang percaya akan Allah dari hati nuraninya, hidup orang beragama dangkal saja. Agama mereka sekiranya lebih-lebih suatu kebiasaan atau tradisi daripada suatu keyakinan pribadi (Theo Huijbes: 1992, 57 ).

Percaya ataupun yakin merupakan suatu proses, sebab hal ini akan tampak kitika orang menghadap yang mutlak dalam kehidupan. Tatkala yang mutlak itu muncul, belum tentu orang sampai percaya bahwa yang muncul didalamnya ialah Allah. Karena itu dalam menghadap yang mutlak bagi manusia dibuka dua alternatif kemungkinan, yaitu menerima yang mutlak sebagai tanda kehadirat Allah atau menolaknya. Bila orang sampai mengaku bahwasanya yang mutlak itu menyertai kehadirat Allah, maka ia sampai pada percaya. Oleh karena itu percaya merupakan hasil suatu pilihan (L. Monden: 1970,346-347). 
Dengan demikian bisa kita pertimbangkan bahwa banyak orang sampai pada percaya atau beriman bukan atas dasar suatu pengalaman eksistensial, melainkan atas dasar pendidikan saja. Jadi mereka percaya sebab mereka hidup dalam lingkungan dimana percaya pada Allah itu sudah merupakah hal biasa. Artinya faktor-faktor lahiriah menyebabkannya sampai percaya atau beriman, sehingga ada kemungkinan bahwa ide-ide agama atau pemahaman agama yang diterima melalui orang lain kurang diselami dalam kehidupan pribadi, atau menurut istilah Muhammad Abduh dalam Risalah Tauhidnya disebut sebagai iman taqlidi yaitu iman tradisionalis yang diterima turun-temurun dari nenek moyangnya. Namun sewajarnya saja bila dikatakan orang itu beriman juga, sebab ia mengakui adanya Allah, akan tetapi kemungkinan untuk tidak beriman ada juga. Sebab percaya kepada Allah itu bisa juga mengundang kemungkinan percaya kepada yang lain-lain sebagai peserta Allah dalam keilahian. Dan sepertinya ini yang selalu jadi problem manusia. Yaitu secara umum, bahwa manusia terlihat memang percaya kepada Allah, namun tidak murni atau sepenuhnya. Dan itulah kenyataannya bahwa diantara manusia memang ada yang tidak percaya sama sekali kepada Tuhan (atheis). Tetapi mereka adalah minoritas kecil dalam masyarakat, katakanlah masyarakat komunis yang secara jelas dianggap atheis.

Tetapi bila dicermati, sesungguhnya atheisme bentuk lain dari politeisme Nurcholish Madjid: 1992,79), dan ini bisa kita perhatikan bahwa semua mereka yang mengaku atheis, yaitu menolak adanya Tuhan, dalam prakteknya bertuhan juga karena mereka memutlakkan sesuatu seperti para pemimpin dan pikiran-pikiran mereka. Bahkan dalam ilmu sosial dipandang komunisme atau atheisme sebagai padanan agama (religion equivalent) dan para pemimpinnya dijadikan padanan-padanan Tuhan -God equivalents, dalam bahasa Al Qur'an andaad- (Q.S. al Baqarah/2:56). Dan praktekpraktek mereka (komunis) yang mencoba mengembangkan sayapnya diabad ini hasilnya justru lebih banyak berwujud politeisme yang begitu kasar dan terus memenjarakan kemanusiaan. Ini bisa dilihat dari politeisme dalam bentuk pemujaan dan kultus terhadap para pemimpinnya, seperti Stalin, Mao ze dung dan Kim. Karena itu problem utama manusia yaitu politeisme atau syirik artinya kepercayaan yang sekalipun berpusat kepada 
Tuhan Yang Maha Esa, namun masih membuka peluang dengan adanya kepercayaan terhadap wujud-wujud lain yang dianggap bersifat ketuhanan.

Dalam Al Qur'an sering kita lihat atau dengar bahwa praktek politeisme atau syirik sebagai dosa yang amat besar (Q.S. Lukman/31:13), yang tak akan diampuni Tuhan (Q.S. al Nisa/4:48). Karena setiap praktek syirik tentu menghasilkan efek pemujaan harkat manusia dan pemerosotannya, dan ini berarti melawan nature atau fitroh manusia sendiri sebagai mahkluk yang paling tinggi dan dimulyakan Tuhan (al Qur'an S. al Maun/107:1akhir dan Q.S. al Isro'/17:70).

Sebab hakekat syirik sama dengan mitos, adalah pengangkatan sesuatu selain Tuhan secara tidak benar, sedemikian rupa sehingga memiliki nilai lebih tinggi daripada nilai manusia sendiri. Dengan kata lain orang yang berpraktek syirik akan dengan sendirinya secara apriori menempatkan diri dan harkat serta martabatnya lebih rendah dari pada obyek yang disyirikkan itu (Nurcholish Madjid:1992, 96).

Begitu juga menurut Erich Fromm, bila ada orang yang memahami Tuhan begitu rupa sehingga penyembahan kepadaNya sebenarnya berada dalam nalar kemustahilan dan berakibat pembelengguan dirinya secara ruhani (Edy A. Efendi: 1999, 35).

Peristiwa diatas terjadi terutama bila konsepsinya tentang Tuhan menghasilkan penggambaran baik visual maupun sekedar khayal tentang wujud Maha Tinggi, sehingga dalam realitasnya jadi sama dengan diri kita sendir, dan inilah yang pada hakekatnya disebut berhala. Jadi setiap berhala adalah buatan manusia sendiri yang menguasai dan membelenggu kebebasan asasi manusia sebagai mahkluk yang mulia. Maka pemujaan berhala adalah jenis alienasi, yaitu situasi ketika orang tidak dapat lagi menguasai buatan tangannya sendiri atau ditundukkan oleh perbuatannya sendiri (Edy A. Efendi: 1999, 35). Dan penyembahan seperti itulah pangkal penderitaan bathin, karena ruhani yang terkungkung. Begitu juga praktek syirik mengindikasikan salah satu hakekat bahwa ia telah kehilangan harkat dan martabatnya yang tinggi. Berarti manusia yang seperti itu tidal lagi mewujudkan pribadi manusia merdeka, maka ia dengan sendirinya menjadi budak atau hamba obyek yang dimuliakannya. 
Karena itu sebagai epilog, demi harkat dan martabat manusia, kita harus menghambakan diri hanya kepada Allah, Tuhan Yang Maha Esa. Atau secara sederhana bila kita lukis melalui grafis, manusia harus melihat keatas hanya kepada Tuhan Yang Maha Esa dan kepada alam harus melihat kebawah. Sedangkan kepada sesamanya, ia harus memotret secara-mendatar (horizontal). Atau dengan ungkapan Cak Nurcholis Madjid, manusia menemukan kepribadiannya yang utuh dan integral, hanya jika memusatkan orientasi transendental hidupnya kepada Allah (Q.S. al Hasyr/59:19). Sebaliknya bagi manusia, menempatkan diri secara harkat dan martabat dibawah sesamanya atau, apalagi dibawah obyek dan gejala alam, akan membuatnya berkepribadian tak utuh. Kerena ia akan kehilangan kebebasannya (Nurcholish Madjid:1992, 97).

\section{Daftar Pustaka}

DR. Yusuf Qardhawi; Merasakan Kehadiran Tuhan, Mitra Pustaka, Yogyakarta, 1999

Sachịco Murata \& William C. Chittick, Trilogi Islam, PT. Rajagarafindo Persada, Jakarta, 1997.

DR. NurCholihs Madjid, Pintu-Pintu Menuju Jjtihad, Paramadina, Jakarta, 1994

DR. Machasin, Menyelami Kebebasan Manusia, Pustaka Pelajar, Yogyakarta, 1996

DR. Nurcholish Madjid, Islam Dotrin Dan Peradaban, Paramadina, Jakarta, 1992

DR. Theo Huijbes, Mencari Allah, Pengantar kedalam Filsafat Ketuhanan, Kanisius, Yogyakarta, 1992,

Prof.DR Harun Nasution, Muhammad Abduh Eg Teologi Rasional Mu'tazilah, Universitas Indonesia Press, Jakarta, 1994.

Muhammad Abduh, Risalah Tauhid, Cairo, Dar Maun, 1366 H. Hal. 111, Jilid 2. L. Monden, Een Taal Waarin Wij Bad Verstaan, Brugge, 1970. dialih bahasakan oleh DR. Theo Huijbers.

Edy A. Efendi, Dekonstruksi Islam Mazhab Ciputat, Zaman Wacana Mulia, Bandung, 1999

Al Qur'an Dan Terjemahannya, Depag RI, Jakarta. 